\author{
(online) $=$ ISSN $2285-3642$ \\ ISSN-L = $2285-3642$ \\ Journal of Economic Development, Environment and People \\ Volume 8, Issue 3, 2019 \\ URL: http://jedep.spiruharet.ro \\ e-mail: office jedep@spiruharet.ro
}

\title{
Opinions and Perceptions of Bank Managers on the Quality of Provision of Internet Banking Services
}

\author{
Luiza Emanuela Bucur ${ }^{1}$, Natalia Manea ${ }^{2}$, Dumitru Goldbach ${ }^{3}$ \\ ${ }^{1}$ Bucharest University of Economic Studies \\ ${ }^{2}$ University POLITEHNICA of Bucharest \\ ${ }^{3}$ Valahia University of Târgoviște
}

\begin{abstract}
Following the accession of Romania to the European Union, the services sector has made important progress. Currently, this sector exceeds 50\% of Romania's GDP. Banking has an important role in the economy by making financial intermediation, attracting deposits and placing credits. The increase in the number of banks on the Romanian market has led to intensification of competition and especially the awareness of the quality of online banking services offered. Therefore, the bank management has to take into account not only the "quality desired or achieved by the bank", but also the quality perceived by the customer.

In this paper we will start with an introduction of bank sector, and then we will present the methodology of research. The design of interview guide is the next step and in the main part of the paper is the analyses of data obtained and interpretation of results.
\end{abstract}

Keywords: online banking, services quality, managers perception

JEL Codes: M31, G29

How to cite: BUCUR, L., MANEA, N., \& GOLDBACH, D. (2019). Opinions and Perceptions of Bank Managers on the Quality of Provisions of Internet Banking Services. Journal of Economic Development, Environment and People, 8(3), 53-59. doi: http://dx.doi.org/10.26458/jedep.v8i3.634

\section{Introduction}

Nowadays the most frequently used banking services are distributed by Internet thanks to the time and cost advantages provided by the Internet.

The banks promote their products and services on professional websites, answer virtually the requests of current and potential customers, maintain survey centres to learn their opinion and sell the whole range of products and services.

The bank no longer represents providers of standardized services, as the bank was perceived no so long ago, but a flexible, generator of new specialisations, and the innovation process is part of the structure of 


\author{
(online) $=$ ISSN $2285-3642$ \\ ISSN-L = $2285-3642$ \\ Journal of Economic Development, Environment and People \\ Volume 8, Issue 3, 2019 \\ URL: http://iedep.spiruharet.ro \\ e-mail: office jedep@spiruharet.ro
}

the new type of banking organization, which represents the prevailing trend in the institutional evolution in the banking sector.

Internet banking is an application which allows for the performance of banking transactions simply, fast and safe. This application has eliminated the waiting queues at the bank counters and increased the quality of financial services. The customers, in order to make transactions by Internet Banking applications, need to have minimal knowledge of computers, and need confidence in these mechanised systems for making transactions.

Quality is one of the main elements which differentiate the companies in services field. By quality, the organizations which provide services maintain existing customers and attract new consumers. (Jeong et all, 2016; Oh\&Kim, 2017; Tonis\&Manea, 2019;)

With reference to the defining elements of the quality of internet banking services, the elements mentioned by the respondents, managers can be grouped according to the dual nature of service quality (Donabedian, 2003), as follows:

- Elements aiming at the technical side of the service provided (refers to the technology and science that exist in the field): realization of transactions; technologies used; functionality of internet banking applications; efficient support lines.

- Elements aiming at interpersonal relations (regarding the application of technology and science in the field): accessibility; professionalism and kindness of the employees on customer support lines; safety and promptness; fastness and security; the possibility of educating customers.

In this context, having as main object the quality of Internet Banking services and following the stimulation of sales of banking services and increase of consumer's confidence, but also the knowledge and satisfaction of their needs we considered necessary to make qualitative research focused especially on the quality of Online Banking services.

\title{
2. Research methodology
}

The research carried out is exploratory, has as purpose a better understanding of the studied problem. Thus, the research was carried out by semi-directed interviews.

The decision-making problem which was at the basis of research included first the detailed knowledge of the interest manifested and the measures taken by the management staff of departments. Taking into account the research purpose, we established the following objectives:

Objective 1: Observation of the interest manifested in the quality of online banking services provided.

Objective 2: Identification of the main problems faced with by the management staff in daily activity to be able to provide higher quality services.

Objective 3: Identification of the meaning conferred to the notion of quality of internet banking services and its defining elements.

Objective 4: Identification of the degree in which the certification of online banking services provided is attested by specific documents. 


\author{
(online) $=$ ISSN $2285-3642$ \\ ISSN-L = 2285 - 3642 \\ Journal of Economic Development, Environment and People \\ Volume 8, Issue 3, 2019 \\ URL: http://jedep.spiruharet.ro \\ e-mail: office jedep@spiruharet.ro
}

\title{
3. Design of the interview guide
}

The instrument used in realization of qualitative research was the interview guide. The interview guide designed is structured by three main themes of discussion, and contains a series of open questions for themes:

- The interest manifested towards the quality of internet banking services:

- $\quad$ Are you concerned about the quality of internet banking services provided?

- What are the problems you have to face with in your daily activity to be able to offer best quality services?

- Definition of the concept of "quality" of internet banking services:

- What do you understand by the "quality of internet banking services" that your company provides?

- What do you think are the defining elements of the quality of internet banking services provided in your company?

- What do you think the customers understand by quality of e-banking services provided in your company?

- Quality management of internet banking services:

- What are the ways by which you monitor the quality of e-banking services offered?

- What elements specific to service are important for customers?

- In your company do you use procedures, standards, guidelines, protocols?

- Do you consider that the current standards meet the safety requirements of the customer?

- $\quad$ Are there documents which certify the quality of banking services provided?

- If you had available all the necessary resources, what would be two changes you would make?

\section{Sample's structure and size}

Taking into account the type of research, which is qualitative, the investigation method selected was the individual interview.

The sample interviewed was composed of the management staff of the internet banking departments and the staff of other banking units in Bucharest.

For the creation of sample we envisaged several reasons, on one hand, its size and structure, quite relevant aspects in specialised literature (Mclntyre et all, 2016), even if the opinions of some authors do not excel in precision (Golafshani, 2003; Silverman, 2013), and on the other hand, the complex concept known as the "power of information" (Malterud, Siersma and Guassora, 2016), considered by the author as the most capable to lead to the achievement of purpose and objectives of research, because they cover multiple issues which are interdependent. 


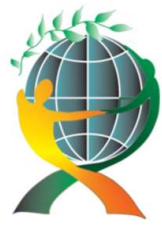

\author{
(online) $=$ ISSN $2285-3642$ \\ ISSN-L = 2285 - 3642 \\ Journal of Economic Development, Environment and People \\ Volume 8, Issue 3, 2019
}

URL: http://jedep.spiruharet.ro

e-mail: office jedep@spiruharet.ro

The size of the sample is represented by 13 persons, a sufficient number for the achievement of objectives and the research purpose, considering that in Romania there are 27 merchant banks and 8 branches of foreign credit institutions (according to the National Bank of Romania, http://www.bnro.ro/Banci-comerciale-1333.aspx).

\begin{tabular}{|c|c|c|c|}
\hline Nr. & Bank & $\begin{array}{c}\text { Total assets in } \\
2018\end{array}$ & $\begin{array}{l}\text { Market } \\
\text { share }\end{array}$ \\
\hline 1. & Alpha Bank România & $64.068 \mathrm{mld}$. lei & $16,28 \%$ \\
\hline 2. & Banca Română de Credite și Investiții & 127 mld lei & $0.03 \%$ \\
\hline 3. & Banca Comercială FEROVIARA & $11.565 \mathrm{mld}$. lei & $2.96 \%$ \\
\hline 4. & Banca Comercială Intesa Sanpaolo România & 4.054 mld.lei & $0.95 \%$ \\
\hline 5 & Banca Comercială Română (BCR) & $64.068 \mathrm{mld}$. lei & $15.83 \%$ \\
\hline 6 & BCR Banca pentru Locuinte & 2921 mld.lei & $0.68 \%$ \\
\hline 7 & Banca de Export-Import a României EXIMBANK & 5.554 mld. lei & $1.3 \%$ \\
\hline 8 & Banca Românească - Membră a Grupului National Bank of Greece & $6.253 \mathrm{mld}$. lei & $1.46 \%$ \\
\hline 9 & Banca Transilvania & 51.776 mld.lei & $13.15 \%$ \\
\hline 10 & Bank Leumi România & 1.183 mld. lei & $0.28 \%$ \\
\hline 11 & BRD - Groupe Société Générale & 50.657 mld. lei & $12,50 \%$ \\
\hline 12 & CEC Bank & 28.194 mld. lei & $7.16 \%$ \\
\hline 13 & Crédit Agricole Bank România & $1.361 \mathrm{mld}$. lei & $0.32 \%$ \\
\hline 14 & Credit Europe Bank (România) & 4.686 mld.lei & $1.10 \%$ \\
\hline 15 & Garanti Bank & 8.959 mld. lei & $2.28 \%$ \\
\hline 16 & Idea Ban & $1.845 \mathrm{mld}$. lei & $0.43 \%$ \\
\hline 17 & Libra Internet Bank & 4.607 mld. lei & $1.08 \%$ \\
\hline 18 & Marfin Bank (România) & 1.973 mld.lei & $0.46 \%$ \\
\hline 19 & OTP Bank România & 9.151 mld. lei & $2.14 \%$ \\
\hline 20 & Patria Bank & 3.465 mld. lei & $0.85 \%$ \\
\hline 21 & First Bank & 10.923 mld. lei & $2.55 \%$ \\
\hline 22 & Porsche Bank România & 568 mld.lei & $0.13 \%$ \\
\hline 23 & ProCredit Bank & $1.311 \mathrm{mld}$ lei & $0.31 \%$ \\
\hline 24 & Raiffeisen Bank & 33.419 mld. lei & $8.49 \%$ \\
\hline 25 & Raiffeisen Banca pentru Locuinte & 625 mld. lei & $0.15 \%$ \\
\hline 26 & UniCredit Bank & $32.687 \mathrm{mld}$. lei & $8.49 \%$ \\
\hline 27 & ING Bank & 27.869 mld lei & $7.08 \%$ \\
\hline
\end{tabular}

Table 1: The credit institutions in Romania depending on size and position held on the market in 2018 Source: Processing of the data of National Bank of Romania

\title{
4. Analyses of data obtained and interpretation of results
}

In order to assure a natural and uninhibited communication, in the interviews we used the nondirectiveness principles (Cătoiu, 2009).

As for the first discussion theme tackled, the interest manifested in the quality of internet banking services, all the respondents were concerned about the quality of internet banking services provided. 


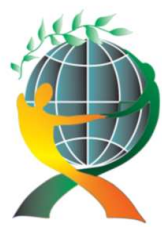

\author{
(online) $=$ ISSN $2285-3642$ \\ ISSN-L = $2285-3642$ \\ Journal of Economic Development, Environment and People \\ Volume 8, Issue 3, 2019 \\ URL: http://jedep.spiruharet.ro \\ e-mail: office jedep@spiruharet.ro
}

Considering the problems they face in their daily activity to provide quality services, most of respondents mentioned that they face various problems such as: the people's fear of change, the legislative framework, the permanent adaptability to the customers' needs and the lack of information of customers.

In this matter, most of respondents claimed that they do not have any problems.

The second perspective of the interest in quality of e-banking services aims at problems faced by the representatives of banks in their daily activity to be able to offer best quality services.

With reference to this question, eleven respondents said they encountered various problems such as: the lack of staff, the lack of information of customers regarding the banking services and taxes, reluctance of certain categories of persons regarding the internet banking services, the high flow of customers, the fear of not being integrated in leading banks, an overloaded internet network sometimes.

The second discussion theme was definition of the concept of "quality" of internet banking services. The respondents were asked what they understood by the quality of internet banking services provided by the company to which they belonged, and answered that they perceived the satisfaction of customers, the safety of services offered, a wide diversity of packages of services and protection of personal data.

One of the answers of respondents understood the quality of services as the assurance of permanent availability of services, the assurance of a prompt customer support line, the assurance of a high level of security, safety and confidentiality of data and the offering of necessary functions for the transactional needs of customers.

As for the defining elements of quality of internet banking services, we can mention that:

The elements identified which aims at interpersonal relations are: safety, promptness, accessibility, professionalism, kindness and politeness of employees on customer support lines; fastness and security.

To the question: "What do you think the customers understand by quality of internet banking services provided in your company?", the respondents provided different answers as follows: seriousness, security, intuition, simple menu, mobility, comfort, easiness, time saving, availability, low costs, safety, confidentiality, protection, accessibility, fast connection, good functioning of software systems, lack of communication problems, confidentiality and safety.

As for the discussion theme regarding the quality management, we noticed that in all banking organizations they use procedures, protocols and guidelines.

As for the question "What are the methods by which you monitor the quality of internet banking services offered?", most of respondents had similar answers: opinion polls, online questionnaires, feedback of customers, administration systems, data monitoring and analysis applications, reporting systems, audit systems.

In the third pillar, they debated the service specific elements with a high importance for customers, among which the safety in online environment, a variety of banking operations, fast access, accessibility from any device, confidentiality, costs, functionality, time, availability, security of transactions and low charges.

According to the interviewed respondents, the main methods by which they monitor the quality of online banking services offered are: feedback of users and use of quality indicators. Also, three quarters of 


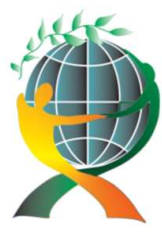

\author{
(online) $=$ ISSN $2285-3642$ \\ ISSN-L = $2285-3642$ \\ Journal of Economic Development, Environment and People \\ Volume 8, Issue 3, 2019 \\ URL: http://jedep.spiruharet.ro \\ e-mail: office jedep@spiruharet.ro
}

managers have regular discussions with the banking staff who comes in direct contact with customers or they apply questionnaires to the customers to obtain feedback.

Their answers regarding the improvements they could bring if they had all the necessary resources are: "I would create a chat between companies under the umbrella of internet banking service, by promotion of their products and creation of partnerships, communication training for operators, more digitalization systems to avoid the waste of time and crowdedness, I would add on application a field which offers the history of transactions from the opening of bank account to date, I would invest more in accessibility, I would increase bank charges to motivate the employees to help increase the portfolio, I would hire more staff and I would invest more in marketing and communication, zero bank charges for customers who resort to internet banking, extension of integration level with other entities in view of expansion of the system.

\title{
5. Conclusions
}

Conclusion for this analysis of interviews, we can claim that all respondents are daily concerned about the quality of services offered, the loyalty of customers and the use of all documents compliant with the laws in force, the market survey and also to bring improvements in everything concerning the applications provided by them. Also, we highlighted a few thinking paters, which thus made possible the systematization of answers. Thus, as for the meaning of the concept quality of internet banking services, they can be characterised from the point of view of elements aiming at the technical side of services (realization of transactions; functionality of applications; technologies used; efficiency of customer support lines) and elements aiming at interpersonal relations (accessibility; professionalism and kindness and politeness of employees on customer support lines; safety and promptness; fastness and security; the possibility of educating customers).

From the perspective of quality management, all the respondents declared that the banking organizations for which they work use guidelines, procedures and protocols. Their adoption by the employees is assured by the training programmes and hierarchical communication.

The changes the management of banking units would adopt highlight the need for a higher training volume for the operators who give customers support, would highlight the promotion of Internet Banking, some of them would eliminate the bank charges, others would increase the cost in order to motivate the employees to help increase the portfolio and would increase accessibility.

\section{References}

[1] H. Oh, K. Kim, (2017) Customer satisfaction, service quality, and customer value: years 2000-2015, International Journal of Contemporary Hospitality.

[2] E. McIntyre, E. Ovington L.A., A.J. Saliba, and C.C. Moran, (2016) Qualitative study of alcohol consumers who choose to avoid wine. Australian Journal of Grape and Wine Research, no.22, pp.182-189.

[3] M. Justin, M. Laurence, A. T. Crecelius, K. Lisa, K. Scheer, A. Patil, (2019)-Multichannel Strategies for Managing Profitability of Business-to-Business Costumers, Journal of Marketing Research

[4] D. Goldbach (2015), Marketing: theory, tests, case studies, Pro Universitaria Publishing House, Bucharest. 


\author{
(online) $=$ ISSN $2285-3642$ \\ ISSN-L = $2285-3642$ \\ Journal of Economic Development, Environment and People \\ Volume 8, Issue 3, 2019 \\ URL: http://jedep.spiruharet.ro \\ e-mail: office jedep@spiruharet.ro
}

[5] Bain \& Co. Inc. (2013), 'Customer Loyalty in Retail Banking: Global Edition 2013,' Boston: Bain \& Co. Inc

[6] Bitner Marz Jo, Ostrom Mary L, Morgan Felicia N (2008), Service Blueprinting: A Practical Technique for Service Innovation, california Management Review, Vol.50, No.3, Spring, pp. 66-94

[7] Bucur (Manea), L., (2015), Distribution strategies of banking services, Proceedings of the 26th International Business Information Management Association Conference, Pages: 1122-1130

[8] I.Cetină, R. Brandabur, M.Constantinescu, (2006), Marketingul Serviciilor. Teorie şi aplicaţii, Editura Uranus: Bucureşti

[9] Jeong MS, Cha JE, Jang DH. (2016) Impact of the Service Quality of Horseback Riding Experience on Customer Satisfaction and Loyalty-In Case of Jangsu Horse Riding Experience Course. Journal of Korean Society of Rural Planning

[10] Donabedian Avedis (2003), An Introduction to Quality Assurance in Health Care, New Yotk, Oxford University Pres

[11] P.Kotler, G. Armstrong, W. Wong, J. Saunders, (2008). Principles of Marketing. London: Prentice Hall

[12] D. Nikolić, M. Stanković, N. Simić, (2014): CRM as a ManagementTool for ImprovingServices, Journal of ProcessManagement - New Technologies, International, Vol. 2, No.1

[13] M. Saunila, J. Ukko, (2013). Facilitating innovation capability through performance measurement: $A$ study of Finnish SMEs, Management Research Review, 36(10), 991-1010. DOI: http://dx.doi.org/10.1108/MRR-11-20110252

[14] D. Silverman, (2013) Doing Qualitative Research. London: Sage Publications Ltd.

[15] R. B. M. Tonis, N.Manea, (2019), Quality Parameters on Higher Education PhD Program in Romania, in Independent Journal of Management \& Production, Volume: 10, Issue: 2, DOI: 10.14807/ijmp.v10i2.855

[16] V. Zeithaml, A., Bitner, J. Marz, D., Gremler (2012) Services marketing: integrating customer focus across the firm, McGraw-Hill Irwin, New York

[17] http://www.bnro.ro/Banci-comerciale-1333.aspx 